\title{
Effect of host-plant genetic diversity on oak canopy arthropod community structure in central Mexico
}

\author{
Efraín Tovar-Sánchez ${ }^{1 *}$, Leticia Valencia-Cuevas ${ }^{1}$, Patricia Mussali-Galante ${ }^{2}$, Rolando Ramírez-Rodríguez \\ and Elgar Castillo-Mendoza' ${ }^{1}$
}

\begin{abstract}
Background: Recently it has been proposed that the genetic diversity of foundation species influences the structure and function of the community by creating locally stable conditions for other species and modulating ecosystem dynamics. Oak species are an ideal system to test this hypothesis because many of them have a wide geographical distribution, and they are dominant elements of the forest canopy. In this study we explored the response of canopy arthropod community structure (diversity and biomass) to the level of genetic diversity of Quercus crassipes and Q. rugosa, two important canopy species. Also, we examined the effect of oak species and locality on some community structure parameters (diversity, biomass, rare species, and richness of arthropod fauna) of canopy arthropods. In total, 160 canopies were fogged in four localities at the Mexican Valley (ten trees per species per locality per season).

Results: $Q$. crassipes registered the highest number of rare species, diversity index, biomass, and richness in comparison with $Q$. rugosa. We found a positive and significant relationship between genetic diversity parameters and canopy arthropod diversity. However, canopy arthropod biomass registered an inverse pattern. Our results support the hypothesis that the genetic diversity of the host-plant species influences the assemblage of the canopy arthropod community.

Conclusions: The pattern found in our study provides a powerful tool when trying to predict the effects of the genetic diversity of the host-plant species on different community structure parameters, which permits assignment of a new conservation status to foundation species based on their genetic diversity.
\end{abstract}

Keywords: Arthropods community; Canopy; Foundation species; Genetic diversity; Quercus

\section{Background}

In the last decade, various studies have documented that genes can have an extended effect beyond the individual, leading to interactions with other species to produce community and ecosystem phenotypes (genetic diversity of foundation species, Whitham et al. 2006). Foundation species have been defined as 'species that structure a community by creating locally stable conditions for other species and by modulating and stabilizing fundamental ecosystem process' (Dayton 1972). This emphasis

\footnotetext{
* Correspondence: efrain_tovar@uaem.mx

'Departamento de Sistemática y Evolución, Centro de Investigación en Biodiversidad y Conservación, Universidad Autónoma del Estado de Morelos, Av. Universidad 1001, Col. Chamilpa, Cuernavaca, Morelos, CP 62209, Mexico Full list of author information is available at the end of the article
}

on foundation species, which are a small subset of the total species in an ecosystem, is because different studies have showed that the analysis of their genetic attributes can reveal strong and predictable effects on communities and ecosystems (Whitham et al. 2003, 2006). For example, studies in cottonwoods (Wimp et al. 2004), eucalyptus (Dungey et al. 2000), oaks (Tovar-Sánchez and Oyama 2006a,b), and willows (Hochwender and Fritz 2004) have evidenced that plant genetics can influence the associations and interactions of the communities associated with these species. The associated communities that have showed a response to the genetic differences within foundation species included taxa as diverse such as soil microbes (Schweitzer et al. 2008),

\section{实}


aquatic invertebrates (Le Roy et al. 2006), mycorrizal fungi (Sthultz et al. 2009), understory plants (Adams et al. 2011), lichens (Lamit et al. 2011), and foliar arthropods (Wimp et al. 2004; Tovar-Sánchez and Oyama 2006b; Tovar-Sánchez et al. 2013). Likewise, ecosystem processes like nutrient cycling (Schweitzer et al. 2008), primary production (Crutsinger et al. 2006), and ecosystem stability (Keith et al. 2010) are affected by the genetics of foundation species.

Most of the evidence that indicates that the genetic diversity within the foundation species of terrestrial and aquatic habitats affecting the distributions of their associated species come from studies under experimental conditions (e.g., Wimp et al. 2007; Keith et al. 2010; Bangert et al. 2012). Nevertheless, it has been suggested that these studies do not show the potential consequences of different levels of genetic diversity in natural settings (Hughes et al. 2008) and may overestimate the importance of host-plant genetic attributes for structuring the communities (Tack et al. 2010, 2011). However, there are several studies in which the results obtained in experimental gardens have been corroborated in natural conditions [e.g., eucalyptus (Whitham et al. 1999; Dungey et al. 2000), and willows (Wimp et al. 2004, 2005)]. These results suggest that a genetic perspective of the community may be applicable, but there is still little understanding about the relative importance of a genetically-based trait variation within the foundation species and other factors for structuring communities in natural conditions (Wimp et al. 2007). These kinds of studies are valuable because they offer a realistic approach to processes that occur under natural conditions and the ability to span relatively large spatial or temporal scales, even when it is difficult to control variables related to the spatial location of host plants that can influence the abundance, distribution, and diversity of the species associated (Vellend and Geber 2005).

In general, both in natural and experimental conditions, the genetic diversity of the host plant has been analyzed under the assumption of the following gradient of genetic diversity [parental < F1 < backcrosses (Whitham et al. 1994; Wimp et al. 2005, 2007; Tovar-Sánchez and Oyama 2006b; Adams et al. 2011)] or considering that genetic diversity increases when more than one genotype is present (Bailey et al. 2006). In contrast, few studies have evaluated the relationship between some measures of host-plant genetic diversity on community metrics (Wimp et al. 2004; Tovar-Sánchez and Oyama 2006b; Tovar-Sánchez et al. 2013).

Canopy arthropod communities have been widely used to evaluate the influence of the genetic diversity of host plants on their associated communities (Whitham et al. 1999; Hochwender and Fritz 2004; Wimp et al. 2004, 2007; Bangert et al. 2006; Tovar-Sánchez and Oyama 2006b; Keith et al. 2010; Tack et al. 2010; Castagneyrol et al. 2012; Tovar-Sánchez et al. 2013). This preference is probably because the canopy is a habitat that can be physically delimited as their arthropod communities are considered the main component in terms of abundance and species diversity (Stork and Hammond 1997). Recently made estimates suggest that the global average richness of this group is of 6.1 million species (Hamilton et al. 2013). Additionally, arthropods play an important role in ecological terms, acting as pollinators, prey, parasites, parasitoids, herbivores, and detritivores (McIntyre et al. 2001).

The effects of the foundation species' genetic characteristics on the arthropod community structure have been detected in metrics as a composition (Bangert et al. 2005; Wimp et al. 2005; Bailey et al. 2006), richness (Dungey et al. 2000; Bangert et al. 2005, 2006, 2008; Crawford and Rudgers 2013) and species diversity (Wimp et al. 2004; Tovar-Sánchez and Oyama 2006b; Ferrier et al. 2012; Tovar-Sánchez et al. 2013). In general, the studies have reported that unique arthropod communities were associated with different genotypes of the host plant (Bangert et al. 2006; Ferrier et al. 2012) and that the richness and species diversity increases as the genotype number also increases [e.g., genotypic diversity (Wimp et al. 2005; Ferrier et al. 2012)] when the genetic diversity of the population increases (Wimp et al. 2004; Tovar-Sánchez and Oyama 2006b; Tovar-Sánchez et al. 2013), or when the individual genetic diversity level increases (Tovar-Sánchez et al. 2013). These patterns have been explained considering that an increase in the hostplant genetic diversity can generate changes in their morphological (Lambert et al. 1995; González-Rodríguez et al. 2004; Tovar-Sánchez and Oyama 2004), phenological (Hunter et al. 1997), and plant architecture (Martinsen and Whitham 1994; Whitham et al. 1999; Bangert et al. 2005), as well as in their secondary chemistry (Fritz 1999; Wimp et al. 2004). These characters constitute a wide array of resources and conditions that can be exploited by their associated herbivores. These results suggest that the effects of genetic diversity on community function can be equal or greater in magnitude compared to species diversity (Hughes et al. 2008), emphasizing the important role that genetic diversity can play in ecological processes. The incorporation of these types of studies into the field of biodiversity research is a logical extension of the theory underlying previous diversity studies, recognizing that genetic diversity is one of the fundamental levels of biodiversity (Hughes et al. 2008).

Knowledge of mechanisms that may be driving the associations between arthropods and plants plays a key role in our understanding of the impact of plant genetic diversity on dependent arthropod communities; however, these mechanisms remain poorly understood 
(Wimp et al. 2007). It has been suggested that phenotypic traits that affect arthropod communities as phenology, physical defenses, and foliar chemistry are features that have a genetic basis (Johnson and Agrawal 2005; Bangert et al. 2006) but have only rarely been linked to both plant genetics and arthropod community structure (Wimp et al. 2007). Also, these attributes can vary between host-plant species (Foss and Rieske 2003; Forkner et al. 2004; Marquis and Lill 2010), affecting both the quantity and quality of resources available to arthropods (Murakami et al. 2007). Understanding the strength of these associations is important as they provide a mechanistic approach to comprehend the relationship between plant genetic diversity, environment, and arthropod community structure.

Oaks (Fagaceae, Quercus) are an ideal system to study the effects of host-plant species genetic diversity on their associated canopy communities because of their high levels of genetic variation (e.g., Tovar-Sánchez et al. 2008; Valencia-Cuevas et al. 2014, 2015); many of their species show a wide geographical distribution and canopy dominance (Valencia 2004), and constitute the habitat of different species. Therefore, some of them can be considered as foundation species. Unfortunately, there are a few studies that have analyzed the influence of the oak host genetic diversity on their canopy arthropods community. In addition, the results of these studies have been contrasting. For example Tovar-Sánchez and Oyama (2006b), reported a positive and significant relationship between population genetic diversity of seven hybrid zones from the $Q$. crassipes $\times Q$. crassifolia complex in Mexico and the canopy endophagous insect community diversity. Similarly, the Q. castanea and $Q$. crassipes plants that were genetically more diverse supported higher richness, diversity, and species density of the canopy ectophagous insects (Tovar-Sánchez et al. 2013) in central Mexico. In contrast, Tack et al. (2010, 2011) found that genetic diversity has little influence on the endophaguos insect community associated to $Q$. robur in Finland. Similar results were reported by Castagneyrol et al. (2012), who found that the host-plant genetic attributes (genetic diversity, relatedness, and genetic identity) did not have a significant effect on the phytophagous insect community structure (endophagous and ectophagous) associated to Q. robur canopy in France. The contrasting results of these investigations show the need for further studies that help us understand the importance of the genetic diversity of oak populations on canopy arthropod communities.

The aims of this study were to analyze the canopy arthropod community structure of Quercus crassipes and Q. rugosa from a genetic perspective, to answer the following questions: 1) Does the genetic diversity of host-plant species affect the arthropod community structure in terms of species diversity and biomass? 2) Does the canopy arthropod-community structure vary between oak host species and localities? We predict that more genetically diverse host plants should support more diverse communities because they offer a wider array of resources and conditions to be exploited.

\section{Methods}

\section{Study sites and oak species}

The Mexican Valley has a well delimitated biogeographical area of $7500 \mathrm{~km}^{2}$ covering several states of Central Mexico surrounded by the main Mexican Sierras. Altitude ranges from $2,230 \mathrm{~m}$ to $2,500 \mathrm{~m}$ at the bottom and $3000 \mathrm{~m}$ to $5450 \mathrm{~m}$ in mountain areas. The most important vegetation types in the Mexican Valley are Abies, Pinus and Quercus forests (Rzedowski and Rzedowski 2001). To minimize geological historic and environmental site effects, we chose four localities [Parque Nacional El Chico (PNECh) in Hidalgo State, Parque Ecológico de la Ciudad de México (PECM) in Mexico City, and Jilotepec and Juchitepec in Mexico State] (Figure 1) that have the following common traits: it has the same geological history [the Mexican Valley is part of the Trans-Mexican Volcanic Belt (Rzedowski and Rzedowski 2001), and its formation process began during the Quaternary-Pliocene (Ferrusquía-Villafranca 1998)], weather (temperate subhumid), altitude (between $2540 \mathrm{~m}$ to $2720 \mathrm{~m}$ ), vegetation type (mature oak), tree age (between $10 \mathrm{~m}$ to $13 \mathrm{~m}$ ), and soil type (volcanic origin or derived from igneous and sedimentary rocks). These areas present almost no local disturbance inside the forest because they are under protection standards or because its rocky substrate prevents agriculture and livestock (Table 1).

Quercus crassipes Humb. \& Bonpl. (Lobatae) and Q. rugosa Née (Quercus) are abundant species in the four study sites. Both can be recognized easily in the field from its leaf characteristics such as shape, size, coloration, and pubescence. Q. crassipes include trees up to $17 \mathrm{~m}$ tall and $1 \mathrm{~m}$ in trunk diameter. Leaves are deciduous, coriaceous, narrowly elliptic, and lanceolate. It flowers in May and bears fruits from September to January. It is distributed within the southeast part of the Sierra Madre Oriental and the Trans-Mexican Volcanic Belt (TVB), between $1900 \mathrm{~m}$ to $3500 \mathrm{~m}$ a.s.l. Q. rugosa includes large trees of up to $20 \mathrm{~m}$ in height with a trunk diameter of $1 \mathrm{~m}$. Leaves are evergreen or semi-deciduous at maturity; they are thick and rigid, strongly rugose, and obovate to elliptic-obovate. The flowering season is in August. Fruits are produced annually (November to March). This species is distributed in the major Mexican mountain ranges [SMOr, Sierra Madre Occidental (SMOc), Sierra Madre del Sur (SMS), Sierra Norte de Oaxaca (SNO), Sierra de Chiapas (SCh), and TVB], at an altitude of $1800 \mathrm{~m}$ to $2900 \mathrm{~m}$ (Rangel et al. 2002). 


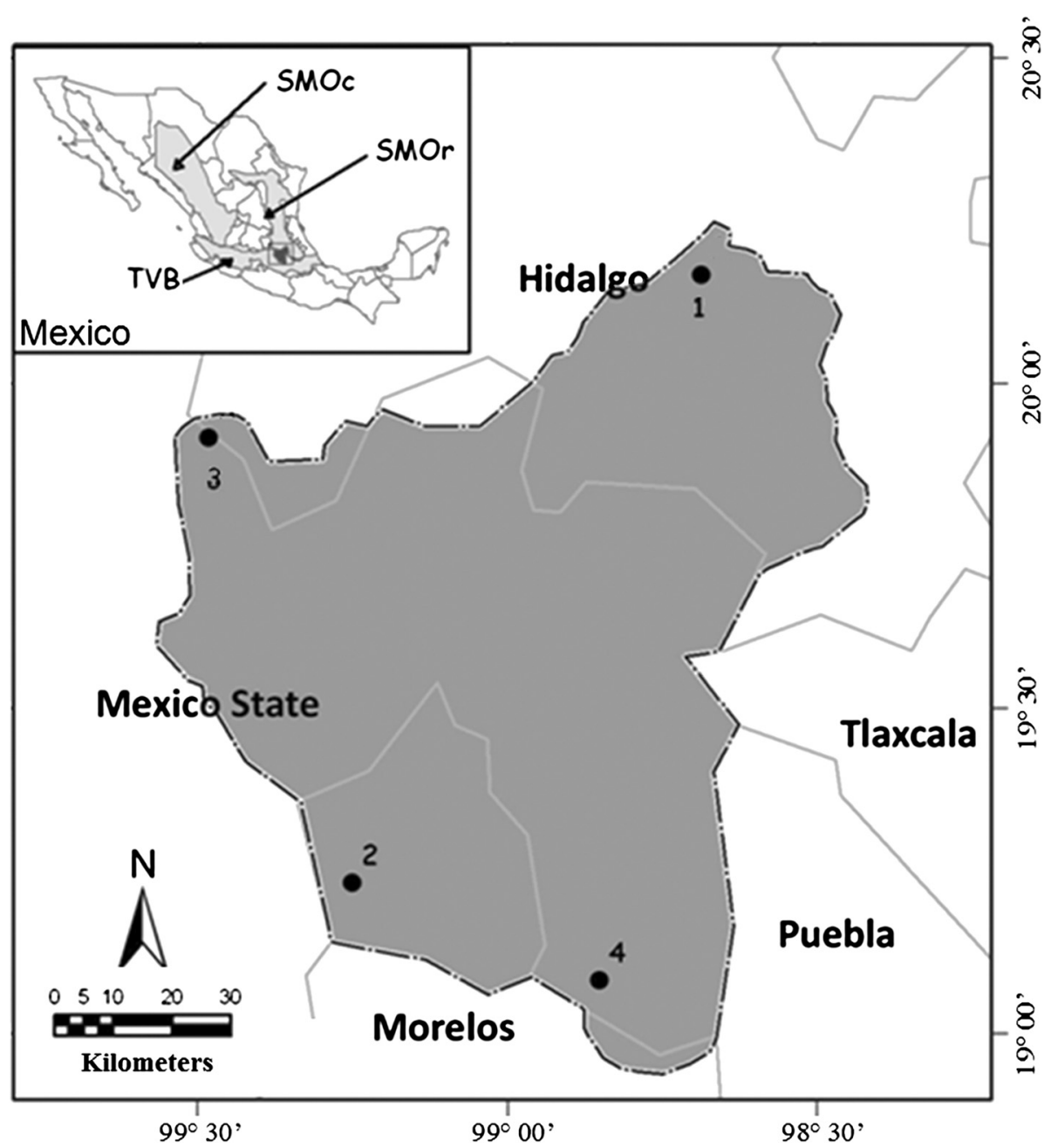

Figure 1 Geographical distribution of the four study sites along the Mexican Valley: 1) Parque Nacional El Chico (PNECh), 2) Parque Ecológico Ciudad de México (PECM), 3) Jilotepec, and 4) Juchitepec. (Gray circle symbol) = Mexican Valley, SMOr = Sierra Madre Oriental, SMOc = Sierra Madre Occidental, TVB = Trans-Mexican Volcanic Belt.

\section{Molecular data}

Leaves with no apparent damage were collected from twenty individuals per species in each study site $[Q$. crassipes $(n=80)$ and $Q$. rugosa $(n=80)$ ]. Leaf tissue was frozen in liquid nitrogen and transported to the laboratory for DNA extraction. Total DNA was extracted and purified by using the DNeasy Plant Mini Kit (Qiagen, Valencia, CA, USA). DNA quantification was done by fluorometric analysis, and DNA quality was visualized by comparing the intensity of bands with known standards of lambda DNA on agarose gels at $0.8 \%$. Genetic analyses were performed using randomly amplified

Table 1 Locality name, state, geographic coordinates, altitude, annual precipitation, slope, and Quercus species

\begin{tabular}{lllllll}
\hline Locality & State & $\begin{array}{l}\text { Latitude }(\mathbf{N}) \mathbf{(} \\
\text { longitude }(\mathbf{W})\end{array}$ & Altitude $(\mathbf{m})$ & $\begin{array}{l}\text { Annual precipitation } \\
(\mathbf{m m})\end{array}$ & $\begin{array}{l}\left.\text { Slope } \mathbf{(}^{\circ}\right) \\
\text { Quercus species }\end{array}$ \\
\hline PNECh & Hidalgo & $20^{\circ} 10^{\prime}, 98^{\circ} 41^{\prime}$ & 2540 & $1,200.2$ & 14 & $\begin{array}{l}\text { Q. crassipes, Q. rugosa, Q. mexicana, } \\
\text { Q. laurina, Q. crassifolia, Q. deserticola, } \\
\text { and Q. greggii. }\end{array}$ \\
PECM & Mexico City & $19^{\circ} 15^{\prime}, 99^{\circ} 11^{\prime}$ & 2620 & $1,084.9$ & 11 & $\begin{array}{l}\text { Q. crassipes, Q. rugosa, Q. castanea, } \\
\text { Q. laeta, and Q. laurina. }\end{array}$ \\
Jilotepec & Mexico State & $19^{\circ} 55^{\prime}, 99^{\circ} 29^{\prime}$ & 2570 & 754.3 & 8 & $\begin{array}{l}\text { Q. crassipes, Q. rugosa, Q. laeta, and } \\
\text { Q. crassifolia }\end{array}$ \\
Juchitepec & Mexico State & $19^{\circ} 05^{\prime}, 98^{\circ} 51^{\prime}$ & 2720 & 729.9 & 9 & Q. crassipes, Q. rugosa, and Q. gregii.
\end{tabular}


polymorphic DNA (RAPDs) and microsatellite markers (SSRs).

For RAPDs, sixty 10-base pair (pb) primers of random sequence (Kits A, B, C; Operon Technologies, Alameda, California, USA) were tested. Eighteen of them were selected based on the amplification results and reproducibility. The selected primers produced a total of 121 polymorphic bands. PCR reactions were done in a PTC100 Programmable Thermal Controller (MJ Research Inc.) as follows: $10 \mathrm{ng}$ of DNA templete, $50 \mathrm{mM} \mathrm{KCl}, 10$ $\mathrm{mM}$ Tris- $\mathrm{HCl}(\mathrm{pH}$ 8.4), $2 \mathrm{mM} \mathrm{MgCl} 2,0.1 \mathrm{mM}$ of each dNTP, $0.2 \mathrm{mM}$ of each primer, and $1 \mathrm{U}$ of Taq polymerase in a final volume of $25 \mu \mathrm{l}$. Reaction conditions were the following: an initial 2 min denaturation step at $94^{\circ} \mathrm{C}$, followed by 45 cycles at $94^{\circ} \mathrm{C}$ for $1 \mathrm{~min}, 1 \mathrm{~min}$ at $36^{\circ} \mathrm{C}$, followed by an annealing temperature at $72^{\circ} \mathrm{C}$ for $30 \mathrm{~s}$ and a final extension at $72^{\circ} \mathrm{C}$ for $7 \mathrm{~min}$. DNA fragments were separated through electrophoresis on agarose gels at $2.8 \%$, stained with ethidium bromide, and developed on an UV light table. The molecular weight of the DNA fragments was estimated by comparison with a $1 \mathrm{~kb}$ DNA ladder.

Microsatellites primers (Ccmp3, Ccmp4, and Ccmp41) were obtained from Weising and Gardner (1999). PCR reactions were done as follows: $15 \mathrm{ng}$ of DNA template, $50 \mathrm{mM} \mathrm{KCl}, 20 \mathrm{mM}$ Tris- $\mathrm{HCl}$ (pH 8.4), $2 \mathrm{mM} \mathrm{MgCl}$, $0.13 \mathrm{mM}$ of each dNTP, $25 \mathrm{mM}$ of each primer, and 0.8 $\mathrm{U}$ of $\mathrm{Taq}$ polymerase in a final volume of $25 \mu$ l. Reaction conditions were an initial denaturation step at $95^{\circ} \mathrm{C}$ for 5 min, followed by 30 cycles at $94^{\circ} \mathrm{C}$ for $1 \mathrm{~min}, 1 \mathrm{~min}$ at the appropriate annealing temperature, followed by $30 \mathrm{~s}$ at $72^{\circ} \mathrm{C}$, and a final extension at $72^{\circ} \mathrm{C}$ for $8 \mathrm{~min}$. Annealing temperature differed for each primer pair. $50^{\circ} \mathrm{C}$ for $\mathrm{Ccmp} 3,48^{\circ} \mathrm{C}$ for $\mathrm{Ccmp} 4$, and $55^{\circ} \mathrm{C}$ for Ccmp41. PCR products were resolved on polyacrilamide gels at $6 \%$ (7 $\mathrm{M}$ urea) at $60 \mathrm{~W}$ for $3 \mathrm{~h}$ in order to determine the polymorphic primers. We measured the length of the amplified microsatellites fragments by running an aliquot of each PCR product on an automatic sequencer ABI 3100 (Applied Biosystems CA, USA) at $35 \mathrm{~W}$ for $80 \mathrm{~min}$ to $90 \mathrm{~min}$ using gene scan ROX-2500 (Applied Biosystems, CA, USA) as size standard. Alleles were scored using the Gene Mapper ver. 3.7 Software (Applied Biosystems, CA, USA).

\section{Canopy arthropod communities}

The arthropod community structure was surveyed in forty trees of both species. Ten individuals per species were vouchered and fogged during rainy (August 2005) and dry (February 2005) seasons on each locality. Sampling was done seasonally, which allowed having a representative annual sample of the canopy arthropodofauna, as suggested by previous studies, which have demonstrated that seasonality modifies both composition and richness in oaks (Tovar-Sánchez and Oyama 2006a; Tovar-Sánchez 2009). The individual trees sampled in this study had a height between $10 \mathrm{~m}$ and $13 \mathrm{~m}$ (mean \pm d.e., $11.0 \pm 0.13 \mathrm{~m})$.

Arthropods were collected by fogging the entire canopy of a single tree with $750 \mathrm{ml}$ of non-persistent insecticide (AqualPy, AgrEvo, Mexico). This insecticide is composed of $30 \mathrm{~g}$ pyrethrine/l and $150 \mathrm{~g}$ piperonyl-butoxide/lL at a concentration of $30 \% \mathrm{v} / \mathrm{v}$. Fallen arthropods from each fogged tree were collected in ten plastic trays (each $0.32 \mathrm{~m}^{2}$ area) located randomly under the crowns. Canopies of trees selected for fogging were isolated from other trees as far as possible, by avoiding overlapping. A measure of the exploited canopy volume was estimated by multiplying the difference between the total height and the height to the lowest branch with denser leaf cover of each tree by 3.2, which is the area of collecting trays (Tovar-Sánchez 2009). The arthropods were separated into morphospecies and after sorted to major orders. All samples were sent to arthropod specialists for taxonomic identification. Abundance of each morphospecies was also counted.

The biomass of canopy arthropods associated to Q. crassipes and Q. rugosa was calculated using the model proposed by Tovar-Sánchez (2009) for oaks in the Mexican Valley. A sample of six individuals/taxa was chosen and then put in a drier at $40^{\circ} \mathrm{C}$ until constant weight. Weight was determined on an analytical scale.

\section{Statistical analysis}

\section{Genetic diversity of oak host species}

Genetic diversity of Q. crassipes and Q. rugosa was estimated for SSRs and RAPDs molecular markers as the average expected heterozygosity $(\mathrm{He})$. We used this parameter of genetic diversity in order to compare the results with others studies in oaks. Genetic data were analyzed with TFPGA v. 1.3 and POPGENE v. 1.31. The data were transformed as $\sqrt{x}$ (Zar 2010), and we used a $t$-student test to examine differences in genetic diversity between species. A Kruskal-Wallis analysis of variance was used to determine differences in oak-species genetic diversity among sites. Thereafter, a Tukey test was conducted to determine significant differences (Zar 2010). Statistical analyses were conducted using STATISTICA for Windows v. 8.0 software (StatSoft 2007).

\section{Canopy arthropods}

The diversity of the canopy arthropod community was estimated at the morphospecies level by using the Shannon-Wiener index $\left(H^{\prime}\right)$. This index was then compared between pairs of localities with a randomization test as described by Solow (1993). This test re-samples 10,000 times from a distribution of species abundances produced by the sum of the two samples. In addition, 
rare species number $(R S)$ was analyzed. Rare species were defined as those species represented by fewer than four individuals in the samples (Tovar-Sánchez and Oyama 2006a).

The arthropods biomass $(W)$ was calculated according to Tovar-Sánchez (2009):

$$
W=\left(e^{-10.644}\right)\left(L^{2.587}\right)
$$

where $W$ is the biomass in mg (dry weight) and $L$ is the body length in millimeters. A mean size and aggregate biomass of the morphospecies population in the sample was estimated from the number of individuals, the mean size of all others measured, and the number of individuals of the same morphospecies. This estimation was calculated for oak canopy arthropod biomass in temperate forests from the Mexican Valley.

Two-Factor Analysis of Variance (Model I fixed effects, Zar, 2010) was conducted to test differences in canopy arthropod biomass, species richness, number of rare species among localities (L), species (S), and interaction $\mathrm{L} \times \mathrm{S}$. Data were transformed as follows: $\mathrm{X}^{\prime}=\log$ $X+1$ (Zar 2010). To determine significant differences in species richness, number of rare species, and biomass between localities, a posterior Tukey test was conducted (Zar 2010). Statistical analyses were conducted using STATISTICA for Windows v. 8.0 software (StatSoft 2007).

General Linear Model (GLM) Analysis of Covariance (Model I fixed effects; Zar 2010) was performed to determine the effect of the locality (L), oak species $(\mathrm{S})$, Genetic diversity, and interaction locality $\times$ oak species $(\mathrm{L} \times \mathrm{S})$ on canopy arthropod biomass and ShannonWiener diversity index.

Diversity $\left(H^{\prime}\right)$ and biomass $(W)$ variables were not correlated with each other. In order to determine the effects of locality, oak species (Q. crassipes, Q. rugosa) and host-plant genetic diversity (expected heterozygosity estimated with microsatellite and RAPDs data) on canopy arthropods diversity index $\left(H^{\prime}\right)$ and biomass, we performed a GLM. The model used a Poisson error distribution and log link function. GLM describes the effects of variables in a multivariate-model setting. This analysis has the advantages that even if a variable has a nonsignificant effect on a variable when subjected to univariate analysis, it may still be a significant variable in a multivariate-model setting when accounting for covariance with other factors (Hillebrand et al. 2008). We pooled the following genetic data from 20 trees within each locality: the community was quantified at the stand level and the occurrence of individual SSRs and RAPDs markers present in each locality, resulting in a unique genetic diversity value for each locality. Locality and oak species were considered as categorical fixed factors and genetic diversity a continuous factor. Statistical analyses were conducted using species diversity and richness version 3.03. and the General Linear Model platform within STATISTICA for Windows v. 8.0 software (StatSoft 2007).

\section{Results}

Genetic diversity of Quercus crassipes and Q. rugosa

Genetic diversity analyses revealed that the expected heterozygosity was significantly higher in $Q$. crassipes than Q. rugosa populations [RAPDs $(t=3.59, P<0.05)$; SSRs $(t=3.45, P<0.05)]$ (Table 2). A Kruskal-Wallis analysis of variance showed significant differences in genetic diversity indexes $(\mathrm{He})$ among populations of $\mathrm{Q}$. crassipes and among populations of $Q$. rugosa (SSR's: $H=11.29$, $P=0.002$; RAPDs: $H=9.87, P=0.009$ ). A multiple comparison Tukey test (RAPDs) showed that Q. rugosa and $Q$. crassipes present the following $\mathrm{He}$ gradient PNECh $=$ PECM $>$ Jilotepec $=$ Juchitepec. While SSRs registered the next $\mathrm{He}$ pattern Q. rugosa: PNECh > PECM > Jilotepec = Juchitepec, and Q. crassipes: PNECh $<$ PECM $>$ Jilotepec $>$ Juchitepec.

\section{Arthropods composition (abundance)}

Canopy arthropod communities were represent by a total of 44,627 arthropods included in 614 morphospecies belonging to the following 24 orders: Araneae, Astigmata, Coleoptera, Cryptostigmata, Dermaptera, Diptera, Entomobryomorpha, Hemiptera, Hymenoptera, Isoptera, Lepidoptera, Mecoptera, Mesostigmata, Neuroptera, Opilionida, Oribatida, Orthoptera, Poduromorpha, Pseudoscorpiones, Psocoptera, Prostigmata, Symphypleona, Thysanoptera, and Trichoptera (nomenclature based on Evans 1992;

Table 2 Genetic diversity parameters for three chloroplast microsatellite loci and 18 RAPD loci, in Quercus crassipes and $Q$. rugosa populations

\begin{tabular}{llll}
\hline & & \multicolumn{2}{l}{ Average expected heterozygosity } \\
\cline { 3 - 4 } Population & $\mathbf{N}$ & RAPDs & SSRs \\
\hline Q. crassipes & 20 & 0.43 & 0.51 \\
PNECh & 20 & 0.46 & 0.58 \\
PECM & 20 & 0.30 & 0.32 \\
Jilotepec & 20 & 0.28 & 0.26 \\
Juchitepec & 20 & $0.37(0.03)^{*}$ & $0.42(0.02)^{*}$ \\
Average & & & 0.40 \\
Q. rugosa & 20 & 0.33 & 0.35 \\
PNECh & 20 & 0.32 & 0.21 \\
PECM & 20 & 0.25 & 0.20 \\
Jilotepec & 20 & 0.23 & $0.48(0.07)^{*}$ \\
Juchitepec & 20 & $0.28(0.02)^{*}$ & \\
Average & 20 & & \\
\hline Numbers in parenth & & & $0.05)$
\end{tabular}

Numbers in parenthesis are standard error. ${ }^{*}$ Significant differences $(P<0.05)$ ( $t$ - student test).

$\mathrm{N}$, sample size; (standard errors). 
Hopkin 1997; Deharveng 2004; Triplehorn and Johnson 2005).

Community structure of canopy arthropods associated to $Q$. crassipes and $Q$. rugosa

Shannon-Wiener diversity $\left(H^{\prime}\right)$, species richness $(S)$, number of rare species $(R S)$, and biomass $(W)$ total values were significantly different $(P<0.05)$ between $Q$. crassipes $\left(H^{\prime}=5.2, S=569, R S=575, W=560.20\right)$ and Q. rugosa $\left(H^{\prime}=4.4, S=450, R S=438, W=313.25\right)$. In addition, in all localities these parameters were higher in $Q$. crassipes than in $Q$. rugosa $(P<0.05)$ (Table 3$)$. PNECh and Juchitepec consistently showed significant differences for $H, S, R S$, and $W$ values in both oak species. In contrast, PECM and Jilotepec had similar values, excepting $H^{\prime}$ in Q. crassipes, and $R S$ for both oak species (Table 3). For Q. crassipes and Q. rugosa, the Shannon-Wiener diversity index $\left(H^{\prime}\right)$ differed significantly between localities $(P<0.05)$, except from PECM and Juchitepec for $Q . r u$ gosa. However, some oak host individuals presented the same diversity values within and among localities for both species. In general, a statistically significant effect of the locality $\left(F_{3,152}=8.151, P<0.001\right)$, the species $\left(F_{1,152}=23.902, P<0.001\right)$ and interaction $\mathrm{L} \times \mathrm{S}$ $\left(F_{2,152}=3.205, P<0.001\right)$ was detected on rare species. Q. crassipes had more number of rare species (less than four individuals) than Q. rugosa. Between localities, PNECh showed the highest number of rare species, followed by PECM, Jilotepec, and Juchitepec (Figure 2). Similar results were registered in arthropod species richness, a statistically significant effect of locality $\left(F_{3,152}=16.023\right.$, d.f. $\left.=3, P<0.001\right)$, species $\left(F_{1,152}=32.007, P<0.001\right)$, and interaction $\mathrm{L} \times \mathrm{S}$

\begin{tabular}{|c|c|c|c|c|}
\hline \multirow[t]{2}{*}{ Locality } & $H^{\prime}$ & $S(\mathrm{CV})$ & $R S(\mathrm{CV})$ & $w$ \\
\hline & & & \multicolumn{2}{|l|}{ Q. crassipes } \\
\hline PNECh & $5.0^{\mathrm{A}}$ & $224(10.11)^{a}$ & $173(10.20)^{a}$ & $427.63(0.042)^{a}$ \\
\hline PECM & $4.4^{\mathrm{B}}$ & $202(6.17)^{a}$ & $165(7.39)^{a}$ & $338.15(0.054)^{\mathrm{ab}}$ \\
\hline Jilotepec & $3.8^{C}$ & $183(9.43)^{a}$ & $124(12.48)^{b}$ & $490.29(0.020)^{b}$ \\
\hline \multirow[t]{2}{*}{ Juchitepec } & $3.0^{\mathrm{D}}$ & $162(6.57)^{b}$ & $113(12.26)^{c}$ & $984.75(0.040)^{c}$ \\
\hline & & & \multicolumn{2}{|l|}{ Q. rugosa } \\
\hline PNECh & $4.6^{\mathrm{A}}$ & $165(8.71)^{a}$ & $127(8.38)^{a}$ & $200.92(0.053)^{a}$ \\
\hline PECM & $4.0^{B}$ & $158(6.09)^{\mathrm{ab}}$ & $119(9.86)^{b}$ & $282.89(0.027)^{b}$ \\
\hline Jilotepec & $3.5^{\mathrm{B}}$ & $153(5.05)^{b}$ & $105(12.68)^{c}$ & $354.19(0.042)^{b c}$ \\
\hline Juchitepec & $2.7^{c}$ & $117(9.43)^{c}$ & $87(13.36)^{c}$ & $415.61(0.027)^{c}$ \\
\hline
\end{tabular}

Same letters show that the mean values for each locality did not differ at $a=0.05$ (capital letters $=$ Solow test; lower case letters $=$ Tukey's test).
$\left(F_{2,152}=3.283, P<0.05\right)$ was detected. For arthropod biomass, a statistically significant effect of the locality $\left(F_{3,152}=12.952, P<0.001\right)$, the species $\left(F_{1,152}=30.741\right.$, $P<0.001)$, and interaction $\mathrm{L} \times \mathrm{S}\left(F_{2,152}=9.708, P<0.001\right)$ was registered.

\section{Effect of genetic diversity of oak host species on canopy} arthropod community

In general, the diversity $\left(H^{\prime}\right)$ and biomass of canopy arthropod species differ significantly among localities, oak species and genetic diversity $(\mathrm{He})$. Also, the interaction locality $\times$ oak species was significant, independently of molecular marker used (SSRs and RAPDs). The only variable that had not a significant effect on canopy arthropod diversity was oak species (S) using both molecular markers, and the interaction locality $\times$ oak species on arthropod biomass (Table 4).

\section{Discussion}

The hypothesis that genetic diversity of foundation species affects the community structure of the canopy arthropods was supported by our results. Also we found that the arthropod community structure was significantly different between host oak species and localities.

\section{Genetic diversity of Quercus crassipes and Q. rugosa}

In general, our study demonstrates that $Q$. crassipes had higher levels of genetic diversity than Q. rugosa. These high genetic diversity levels in $Q$. crassipes may be due to incipient reproductive barriers, which facilitate interspecific crosses with closely related species. For example, Valencia (1994) proposed that a group of oaks conformed by Q. affinis, Q. crassipes, Q. crassifolia, Q. laurina, Q. mexicana, and Q. rubramenta may experience genetic exchange when they occur in sympatric/mixed stands. This last scenario has been corroborated by Tovar-Sánchez and Oyama (2004) for the Q. crassipes $\times$ Q. crassifolia complex, González-Rodríguez et al. (2004) for the $Q$. laurina $\times Q$. affinis complex, and Valencia-Cuevas et al. (2015) for Q. castanea, Q. laurina, and Q. crassifolia. The species mentioned above are distributed along the Mexican Valley, a fact that may facilitate the genetic exchange with $Q$. crassipes.

Moreover, when the study sites are classified by their number of red oak species, the following pattern is observed PNECh > PECM > Jilotepec > Juchitepec, which is congruent with the genetic diversity pattern for both species (Table 2). Therefore, we suggest a possible relationship between the number of red oak species and their genetic diversity levels. This is supported by the work of Valencia-Cuevas et al. (2014), who reported an increase on the levels of $Q$. castanea genetic diversity as the local richness of the red oak community also increases. 


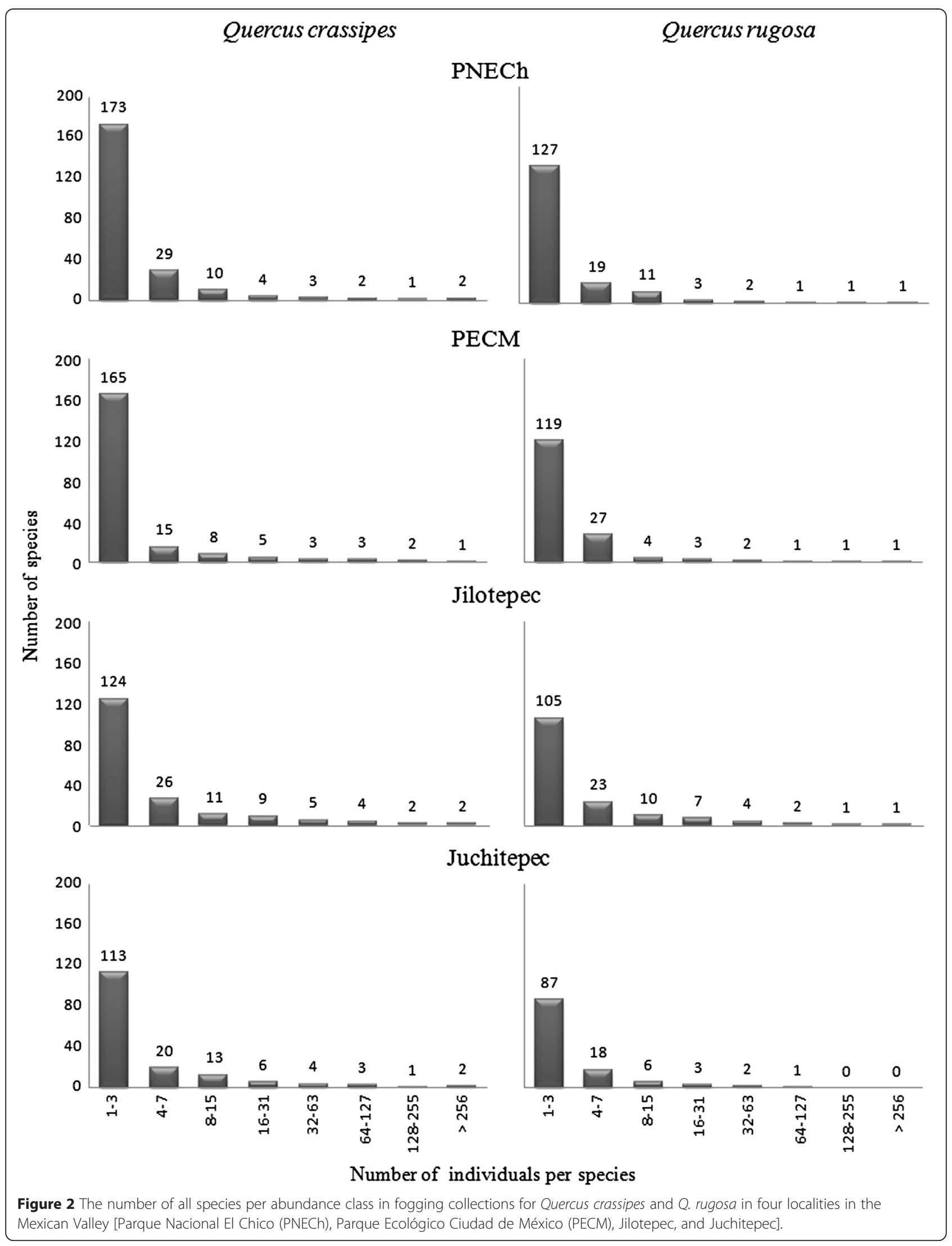


Table 4 Results from the General Lineal Model (GLM Analysis of Covariance) testing the effects of locality (PNECh, PECM, Jilotepec, and Juchitepec), oak species (Quercus crassipes and Q. rugosa), host-plant genetic diversity (expected heterozigosity, estimated with microsatellites and RAPDs data), and the interaction $L \times S$ on canopy arthropod diversity and biomass

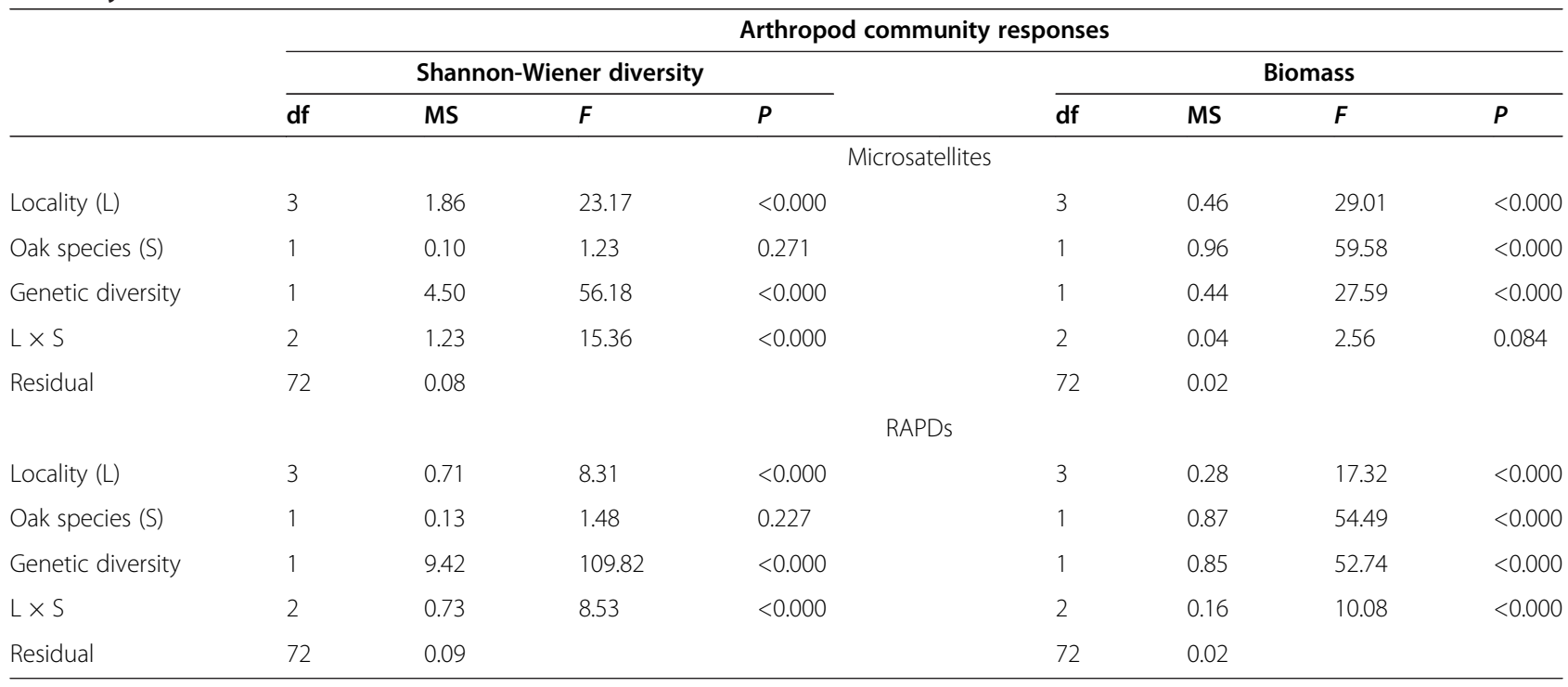

Particularly, the hybridization phenomenon has been documented between Q. crassipes and Q. crassifolia in Jilotepec (Tovar-Sánchez and Oyama 2006a), and possible hybrids have been observed in PNECh between $Q$. crassipes and Q. crassifolia (S. Valencia, Science Faculty Herbarium, Universidad Nacional Autónoma de México). In addition, there is evidence that Q. rugosa hybridizes with Q. glabrescens at the PNECh (Núñez-Castillo et al. 2011). The above statements support that Q. crassipes and Q. rugosa presents higher genetic diversity levels at the PNECh as a result of interspecific hybridization, since genetic combinations produced by introgression exceeds the possible combinations resulting from mutational processes (Anderson 1949). This may increase the genetic diversity levels.

\section{Effect of genetic diversity of oak host species on canopy arthropod community}

We found a significant effect of the host genetic diversity on parameters of arthropod community structure [Shannon-Wiener diversity $\left(H^{\prime}\right)$ and biomass $(W)$ ]. These results are consistent with those reported by Wimp et al. (2004), who found that the cottonwood's genetic diversity (heterozygosity) (Populus fremontii $\times$ P. angustifolia) has a significant influence on the diversity $\left(H^{p}\right)$ of their associated gall-forming insects, explaining about $60 \%$ of the variability in the community. Similarly, Tovar-Sánchez and Oyama (2006b) reported that the oak genetic diversity (Shannon-Wiener) (Quercus crassipes $\times$ Q. crassifolia) explained about $78 \%$ of the diversity $\left(H^{\prime}\right)$ of associated gallforming insects. This could be explained due to the high level of specialization of gall-forming insects, since they have been considered as species-organ-tissue specific (Stone et al. 2002). This high level of specialization along with their tight relationship with host species may account for their high level of response to host species in comparison to canopy epiphyte insects.

Host-plant genetic diversity not only has direct impact on the associated community of herbivores, yet, its effects can be extended to the following trophic levels indirectly, by promoting a cascade effect throughout the community (Whitham et al. 2006). For example, an increase in host-plant genetic diversity can promote an increase in their architectural complexity and nutritional quality (Bailey et al. 2004). This may favor a greater density of herbivores (Bailey et al. 2006), depredation intensity, and parasitism degree (Sarfraz et al. 2008).

Canopy arthropod community structure $(H, S, R S$, and $W$ ) differed significantly between host species. $Q$. crassipes had the highest values in all the parameters mentioned. This pattern may be explained by the higher dominance and genetic diversity of $Q$. crassipes in all localities. In general, this species dominates oak forests, and its great abundance and genetic diversity may be favoring the availability of resources and conditions, resulting in a more complex arthropod assemblage. These results are supported by several studies that have showed that the increase in genetic variation in plants can generate a large amount of variation in morphological (González-Rodríguez et al. 2004; Tovar-Sánchez and Oyama 2004, López-Caamal et al. 2013), phenological (Hunter et al. 1997), architectural (Bangert et al. 
2005), and chemical traits (Fritz 1999). All these features are genetically controlled given that arthropods are sensitive to these host-plant traits; it is not surprising that they would closely track the plant genetic via these traits (Bangert et al. 2008). A similar response has been reported in canopy cottonwoods (Wimp et al. 2004), willows (Hochwender and Fritz 2004), and eucalyptus (Dungey et al. 2000).

In general, the canopy arthropod community associated with Q. crassipes and Q. rugosa was represented by few abundant species and many rare species, which agrees with that reported in other studies (e.g., Tovar-Sánchez 2009). Particularly, the results showed that the canopy of $Q$. crassipes supports a greater number of rare species than Q. rugosa. Probably because the first species offers a wider range of resources and conditions as a result of their genetic diversity as already explained. This is supported by the work of Tovar-Sánchez and Oyama (2006a), who reported a greater number of rare species in hybrids of $Q$. crassipes $\times$ Q. crassifolia complex, where genetic diversity is increased.

These studies have suggested that the areas with more genetically diverse hosts can be considered as centers of diversity and species richness (Tovar-Sánchez and Oyama 2006a), areas of great ecological and evolutionary activity, providing new habitats for associated communities. Our results showed that the arthropod diversity $\left(H^{p}\right)$ for $Q$. crassipes and $Q$. rugosa presents the following gradient: PNECh $>$ PECM > Jilotepec $>$ Juchitepec. In general, this pattern is consistent with the level of genetic diversity among localities. In addition, this pattern could be related to the number of arboreal species growing in simpatry with $Q$. crassipes and Q. rugosa in each locality, a phenomenon that is known as "associational susceptibility" (White and Whitham 2000), in which plant species present greater diversity of herbivores when spatially associated with heterospecific neighbors (White and Whitham 2000).

\section{Implications for conservation}

Mexico is one of the centers of diversification of the genus Quercus with more than 161 species (Valencia 2004). Oak and pine trees are the dominant species in most of the temperate forests of Mexico and they provide fundamental ecosystem services. In particular, some oak species can be considered foundation species. Unfortunately, deforestation rates are increasing in Mexican forests ( $\approx 314$ thousand ha/year, FAO 2006) with potentially serious implications. From a conservation perspective, this study suggests that the maintenance of the genetic diversity of the host plants is crucial for the preservation of associated species. Also, it is a priority to assign a new conservation status for foundation species and propose strategies to safeguard mechanism to maintain their genetic diversity. When the foundation species are the habitat, a loss of genetic diversity will result in a loss of habitat that could have a potential effect on species across multiple trophic levels and major taxonomic groups (Bangert et al. 2005). This serves as a guide for future conservation efforts and provides a mechanism for why conservation efforts may fail if they do not consider the community consequences of genetic variation in foundation species, because their extended phenotypes affect the rest of the community.

\section{Conclusions}

In order to understand the assembly of natural communities, some factors such as interactions, degree of disturbance, type and quality of resources and environmental conditions have been widely studied. Recently, a genetic approach has revealed that the influence of genetic diversity extends to the community level. In this study, we found a genetic diversity effect of oak host species on canopy arthropod community, regardless of the molecular marker used as well as the host plant species type. Since oaks represent dominant trees in Mexican temperate forest, these findings may be important locally and at a landscape level. The consideration of the genetic diversity of the foundation species can be a general and efficient approach to conserving processes and diverse assemblages in nature. The development of this community genetic perspective should help us to understand the natural world, its complex interactions, and the effects of anthropogenic change.

\section{Competing interests}

The authors declare that they have no competing interests.

\section{Authors' contributions}

All authors participated in the review, topic design, in the data analyses, and in the manuscript writing. Also, all authors read and approved the final version of the manuscript.

\section{Acknowledgements}

We express our thanks to the following specialists on arthropod and plant taxonomy for their interest and assistance in this project: S. Valencia-Avalos (Oaks), M. Mora-Jarvio (Oaks), C. Mayorga (Hemiptera), G. Ortega León (Hemiptera), O. Ávalos (Hymenoptera), M. Menendez (Araneae), B. Mejía (Collembola and Acari), A. Godínez (Diptera), and A. Ibarra Vázquez (Lepidoptera). This research was supported by grants from CONACYT- Mexico (61725) and PROMEP/103.5/07/2674 to E.T.S.

\section{Author details}

'Departamento de Sistemática y Evolución, Centro de Investigación en Biodiversidad y Conservación, Universidad Autónoma del Estado de Morelos, Av. Universidad 1001, Col. Chamilpa, Cuernavaca, Morelos, CP 62209, Mexico. 'Laboratorio de Investigaciones Ambientales, Centro de Investigación en Biotecnología, Universidad Autónoma del Estado de Morelos, Av. Universidad 1001, Col. Chamilpa, Cuernavaca, Morelos, CP 62209, Mexico.

Received: 12 November 2014 Accepted: 23 April 2015

Published online: 12 May 2015

\section{References}

Adams RI, Goldberry S, Whitham TG, Zinkgraf, Dirzo R (2011) Hybrization among dominant tree species correlates positively with understory plant diversity. Am J Bot 98:1623-1632. 
Anderson E (1949) Introgressive Hybridization. John Wiley, New York

Bailey JK, Bangert RK, Schweitzer JA, Trotter RT III, Shuster SM, Whitham TG (2004) Fractal geometry is heritable in trees. Evolution 59:2100-2102

Bailey JK, Woolley SC, Lindroth RL, Whitham TG (2006) Importance of species interactions to community heritability: a genetic basis to trophic-level interactions. Ecol Lett 9:78-85

Bangert RK, Turek RJ, Martinsen GD, Wimp GM, Bailey JK, Whitham TG (2005) Benefits of conservation of plant genetic diversity on arthropod diversity. Conserv Biol 19:379-390

Bangert RK, Allan GJ, Turek RJ, Wimp GM, Meneses N, Martinsen GD, Keim P, Whitham TG (2006) From genes to geography: a genetic similarity rule for arthropod community structure at multiple geographic scales. Mol Ecol 15:4215-4228

Bangert RK, Lonsdorf EV, Wimp GM, Shuster SM, Fischer D, Schweitzer JA, Allan GJ, Bailey JK, Whitham TG (2008) Genetic structure of a foundation species: scaling community phenotypes from the individual to the region. Heredity 100:121-131

Bangert RK, Ferrier SM, Evans L, Kennedy K, Grady KC, Hersch-Green E, Allan GJ, Whitham TG (2012) The proportion of three foundation plant species and their genotypes influence an arthropod community: restoration implications for the endangered southwestern willow flycatcher. Res Ecol, doi:10.1111/ j.1526-100X.2012.00910.X

Castagneyrol B, Lagache L, Giffard B, Kremer A, Jactel H (2012) Genetic diversity increases insect herbivory on oak saplings. PloS one 7(8), e44247

Crawford K, Rudgers J (2013) Genetic diversity within a dominant plant outweighs plant species diversity in structuring an arthropod community. Ecology 94:1025-1035

Crutsinger GM, Collins MD, Fordyce JA, Gompert Z, Nice CC, Sanders DJ (2006) Plant genotypic diversity predicts community structure and governs an ecosystem process. Science 313:966-968

Dayton PK (1972) Toward an understanding of community resilience and the potential effects of enrichments to the Benthos at McMurdo Sound, Antarctica. In: Parker BC (ed) Proceedings of the Colloquium on Conservation Problems in Antarctica. Allen Press. Lawrence, Kansas

Deharveng $L$ (2004) Recent advances in Collembola systematic. Pedobiologia 48:415-433

Dungey HS, Potts BM, Whitham TG, Li HF (2000) Plant genetics affects arthropod community richness and composition: evidence from a synthetic eucalypt hybrid population. Evolution 54:1938-1946

Evans GO (1992) Principles of Acarology. CAB International, England

FAO (2006) Global Forest Resources Assessment 2005: progress towards sustainable forest management. Forestry Paper 147. Available from: http:// www.fao.org (accessed October 2007). United Nations Food and Agriculture Organization (FAO), Rome

Ferrier SM, Bangert RK, Hersch-Green E, Bailey JK, Allan GJ, Whitham TG (2012) Unique arthropod communities on different host-plant genotypes results in greater arthropod diversity. Arthropod-Plant Inte 6:187-195

Ferrusquía-Villafranca I (1998) Geología de México: una Sinopsis. In: Ramamoorthy TP, Bye R, Lot A, Fa J (eds) Diversidad Biológica de México: Orígenes y Distribución. Instituto de Biología UNAM, México

Forkner RE, Marquis RJ, Lill JT (2004) Feeny revisited: condensed tannins as anti-herbivore defenses in leaf-chewing herbivore communities of Quercus. Ecol Entomol 29:174-187

Foss LK, Rieske LK (2003) Species-specific differences in oak foliage affect preference and performance of gypsy moth caterpillars. Entomol Exp Appl 108:87-93

Fritz RS (1999) Resistance of hybrid plants to herbivores: genes, environment, both? Ecology 80:382-391

González-Rodríguez A, Arias DM, Valencia S, Oyama K (2004) Morphological and RAPD analysis of hybridization between Quercus laurina and Quercus affinis (Fagaceae), two Mexican red oaks. Am J Bot 91:401-409

Hamilton AJ, Novotny V, Waters EK, Basset Y, Benke KK, Grimbacher PS, Miller SE, Samuelson GA, Weiblen GD, Yen JDL, Stork NE (2013) Estimating global arthropod species richness: refining probabilistic models using probability bounds analysis. Oecologia 171:357-365

Hillebrand H, Frost P, Liess A (2008) Ecological stoichiometry of indirect grazer effects on periphyton nutrient content. Oecologia 155:619-630

Hochwender CG, Fritz RS (2004) Plant genetic differences influence herbivore community structure: evidence from a hybrid willow system. Oecologia 138:547-557

Hopkin PS (1997) Biology of the Springtails (Insecta: Collembola). Oxford University Press, England
Hughes AR, Inouye BD, Johnson TJ, Underwood N, Vellend M (2008) Ecological consequences of genetic diversity. Ecol Lett 11:1-15

Hunter MD, Varley GC, Gradwell GR (1997) Estimating the relative roles of top-down and bottom-up forces on insect herbivore populations: a classic study revisited. Proc Nat Acad Sci 94:9176-9181

Johnson MT, Agrawal AA (2005) Plant genotype and environment interact to shape a diverse arthropod community on evening primrose (Oenothera biennis). Ecology 86:874-885

Keith AR, Bailey JK, Whitham TG (2010) A genetic basis to community repeatability and stability. Ecology 91:3398-3406

Lambert L, McPherson RM, Espelie KE (1995) Soybean host plant resistance mechanisms that alter abundance of white-flies (Homoptera: Alyrodidae), Environ Ecol 24:1381-1386

Lamit L, Wojtowicz T, Kovacs Z, Wooley SC, Zinkgraf M, Whitham TG, Lindroth RL, Gehring CA (2011) Hybridization among foundation tree species influences the structure of associated understory plant communities. Botany 89:165-174

Le Roy CJ, Whitham TG, Keim P, Marks JC (2006) Plant genes link forest and streams. Ecology 87:255-261

López-Caamal A, Mussali-Galante P, Valencia-Cuevas L, Ramírez JJ, Flores KV, Tovar-Sánchez E (2013) Transgressive character expression in hybrid zones between the native invasives Tithonia tubaeformis and Tithonia rotundifolia (Asteraceae) in Mexico. Plant Syst Evol 299:1781-1792

Marquis RJ, Lill JT (2010) Impact of plant architecture versus leaf quality on attack by leaf-tying caterpillars on five oak species. Oecologia 163:203-213

Martinsen GD, Whitham TG (1994) More birds nest in hybrid cottonwoods. Wilson Bull 106:474-481

McIntyre NE, Rango J, Fagan WF, Faeth SH (2001) Ground arthropod community structure in a heterogeneous urban environment. Landscape Urban Plan 52:257-274

Murakami M, Hirao T, Ichie T (2007) Comparison of lepidopteran larval communities among tree species in a temperate deciduous forest, Japan. Ecol Entomol 32:613-620

Núñez-Castillo SM, Álvarez-Moctezuma JG, Zavala-Chávez F, Espinosa-Robles P (2011) Morphologic and habitat analysis of Quercus glabrescens $\times$ Q. rugosa hybrid. Rev Mex Cien For 2:83-100

Rangel SR, Rojas E, Aguilar M (2002) El género Quercus (Fagaceae) en el Estado de México. Ann Missouri Bot Gard 89:551-593

Rzedowski J, Rzedowski GC (2001) Flora Fanerogámica del Valle de México. Instituto de Ecología, A. C., Centro Regional del Bajío. Comisión Nacional para el Conocimiento y Uso de la Biodiversidad, México

Sarfraz M, Dosdall LM, Keddie BA (2008) Host plant genotype of the herbivore Plutella xylostela (Lepidopetera: Plutellidae) affects the performance of its parasitoid Diadegma insulare (Hymenoptera: Ichneumonidae). Biol Control 44:42-51

Schweitzer JA, Bailey JK, Fischer DG, LeRoy CJ, Londsford EV, Whitham TG, Hart SC (2008) Plant-soil microorganisms interactions: a heritable relationship between plant genotype and associated soil microorganisms. Ecology 89:773-781

Solow RA (1993) A simple test for change in community structure. J Anim Ecol 62:191-193

Statsoft INC (2007) STATISTICA for Windows. Tulsa, USA

Sthultz CM, Whitham TG, Kennedy K, Deckert R, Gehring CA (2009) Genetically based susceptibility to herbivory influences the ectomycorrhizal fungal communities of a foundation tree species. New Phytol 184:657-667

Stone GN, Schönrogge K, Atkinson RJ, Pujade-Villar J (2002) The population biology of gall wasp (Hymenoptera: Cynipidae). Ann Rev Entomol 47:633-668

Stork NE, Hammond PM (1997) Sampling arthropods from treecrowns by fogging with knockdown insecticides: lessons from studies of oak tree beetle assemblages in Richmond Park. In: Stork NE, Adis J, Didham RK (eds) Canopy Arthropods. Chapman and Hall, London, pp 3-26

Tack AJ, Ovaskainen O, Pulkkinen P, Roslin T (2010) Spatial location dominates over host plant genotype in structuring an herbivore community. Ecology 91:2660-2672

Tack AJ, Johnson MTJ, Roslin P (2011) Sizing up community genetics: it's a matter of scale. doi: 10.1111/j.1600-0706.2011.19926.x

Tovar-Sánchez E (2009) Canopy arthropod community within and among oak species in central Mexico. Current Zool 55:132-144

Tovar-Sánchez E, Oyama K (2004) Natural hybridization and hybrid zones between Quercus crassifolia and Quercus crassipes (Fagaceae) in Mexico: morphological and molecular evidence. Am J Bot 91:1352-1363 
Tovar-Sánchez E, Oyama K (2006a) Community structure of canopy arthropods associated in Quercus crassifolia × Quercus crassipes complex. Oikos 112:370-381

Tovar-Sánchez E, Oyama K (2006b) Effect of hybridization of the Quercus crassifolia $\times Q$. crassipes complex on the community structure on endophagous insects. Oecologia 147:702-713

Tovar-Sánchez E, Mussali-Galante P, Esteban-Jiménez R, Piñero D, Arias DM, Dorado O, Oyama K (2008) Chloroplast DNA polymorphism reveals geographic structure and introgression in the Quercus crassipes $\times$ Quercus crassifolia hybrid complex in Mexico. Botany 86:228-239

Tovar-Sánchez E, Valencia-Cuevas L, Castillo-Mendoza E, Mussali-Galante P, Pérez-Ruíz RV (2013) Association between individual genetic diversity of two oak host species and canopy arthropod community structure. Eur J Forest Res. doi 10.1007/s10342-012-0665-y

Triplehorn CA, Johnson NF (2005) Borror and DeLong's Introduction to the Study of Insects. Brooks/Thomson Cole, USA

Valencia S (1994) Contribución a la Delimitación Taxonómica de 3 Especies del Género Quercus sub. Dissertation, Universidad Nacional Autónoma de México, Erytrobalanus

Valencia S (2004) Diversidad del género Quercus en México. Bol Soc Bot Méx 75:33-53

Valencia-Cuevas L, Piñero D, Mussali-Galante P, Valencia-Ávalos S, Tovar-Sánchez E (2014) Effect of a red oak species gradient on genetic structure and diversity of Quercus castanea (Fagaceae) in Mexico. Tree Genet Genomes 10:641-652

Valencia-Cuevas L, Mussali-Galante P, Piñero D, Castillo-Mendoza E, RangelAltamirano G, Tovar-Sánchez E (2015) Hybridization of Quercus castanea (Fagaceae) across a red oak species gradient in Mexico. Plant Syst Evol. 301:1085-1097

Vellend M, Geber MA (2005) Connections between species diversity and genetic diversity. Ecol Lett 8:767-781

Weising K, Gardner R (1999) A set of conserved PCR primers for the analysis of the simple sequence repeat polymorphisms in chloroplast genomes of dicotyledonous. Genome 42:9-19

White JA, Whitham TG (2000) Associational susceptibility of cottonwood to a box elder herbivore. Ecology 81:1795-1803

Whitham TG, Morrow PA, Potts BM (1994) Plant hybrid zones as centers of biodiversity: the herbivore community of two endemic Tasmanian eucalypts. Oecologia 97:481-490

Whitham TG, Martinsen GD, Floate KD, Dungey HS, Potts BM, Keim P (1999) Plant hybrid zones affect biodiversity: tools for a genetic based understanding of community structure. Ecology 80:416-428

Whitham TG, Young WP, Martinsen GD, Gering CA, Scheweitzer JA, Shuster SM, Wimp GM, Fischer DC, Bailey JK, Lindroth RL, Woolbright S, Kuske R (2003) Community and ecosystem genetics: a consequence of the extended phenotype. Ecology 84:559-573

Whitham TG, Bailey JK, Scheweitzer JA, Shuster SM, Bangert RK, LeRoy CJ, Lonsdorf EV, Allan GJ, DiFazio SP, Potts BM, Fischer DC, Gehring CA, Lindroth RL, Marks JC, Hart SC, Wimp GM, Wooley SC (2006) A framework for community and ecosystem genetics: form genes to ecosystems. Nature 7:510-523

Wimp GM, Young PW, Woolbright SA, Martinsen GD, Keim P, Whitham TG (2004) Conserving plant genetic diversity for dependent animal communities. Ecol Lett 7:776-780

Wimp GM, Martinsen GD, Floate KD, Bangert RK, Whitham TG (2005) Conserving plant genetic diversity for dependent animal community structure and diversity. Evolution 59:61-69

Wimp GM, Wooley S, Bangert K, Young WP, Martinsen GD, Keim P, Rehill B, Lindrot RL, Whitham TG (2007) Plant genetics intra-annual variation in phytochemestry and arthropod community structure. Mol Ecol 16:5057-5069

Zar JH (2010) Byostatistical Analysis. Prentice-Hall, Inc. USA

Submit your manuscript to a SpringerOpen ${ }^{\circ}$ journal and benefit from:

- Convenient online submission

- Rigorous peer review

- Immediate publication on acceptance

- Open access: articles freely available online

- High visibility within the field

- Retaining the copyright to your article

Submit your next manuscript at springeropen.com 